\title{
AN EXPERIMENTAL STUDY ON THE PERFORMANCE OF VERTICAL BASIN SOLAR STILL
}

\author{
T.V.Arjunan ${ }^{a}$, T.G.Sakthivel ${ }^{b}$ \\ ${ }^{a}$ Department of Mechanical Engineering, Coimbatore Institute of Engineering and Technology, Coimbatore, \\ Tamilnadu, India. \\ arjun_nivi@yahoo.com \\ ${ }^{b}$ Department of Mechanical Engineering, Panimalar Intitute of Technology, Chennai, Tamilnadu, India \\ sakthitgmanisha@gmail.com
}

\begin{abstract}
In the present study, a new experimental approach is proposed to enhance the performances of the conventional single slope solar still using vertical basin at inner wall surfaces. Main objectives of this study are, to increase the distilled output of solar still by utilizing heat energy available inside vertical surfaces and to find out the optimum thickness of vertical basin experimentally. The experimental system involves six identical solar stills, one of the stills is conventional and remaining stills have vertical basin with different thicknesses $(3,6,9,12$ and $15 \mathrm{~mm})$. Solar stills are fabricated with an effective area of $0.009 \mathrm{~m}^{2}$ and the transparent glass angle is $11^{\circ}$. The experiments were conducted on 19.02.2016 with depth of water $20 \mathrm{~mm}$. The results show that (i) productivity of vertical basin solar stills are higher than the conventional still, (ii) heat loss from inner wall surfaces to outer wall surfaces are reduced considerably in vertical basin still (iii) optimum thickness of vertical basin is $12 \mathrm{~mm}$. To conclude introducing vertical basin in conventional still improves the performance of the still.
\end{abstract}

Keywords: vertical basin, solar still, thickness, single slope

\section{Introduction}

Distillation process is one of the considered simplest and widely adopted techniques in conversion of seawater to fresh water. Use of solar energy for water distillation is the simplest and economical method for the arid areas where solar intensity is abundant and fresh water is scarce. Solar distillation could benefit developing countries in several ways: A few such beneficiaries are, the daily operation and routine maintenance is simple, no skilled labour is demanded, potential to use local materials, no energy cost, not subject to fuel supply interruptions etc. During to the simplicity of apparatus design work in field of solar distillation the progress is in for more than one hundred years. The lower distillate output limits the usage of solar still. Depth of water in the basin, thickness of glass cover, thickness of insulation etc., are a few parameters that could affect the performance of conventional solar still. Considering these drawbacks, many researchers have tried to improve the productivity of conventional stills by making various changes.

The productivity has been improved about $145.5 \%$ by introducing corrugated surfaces inside the still [1]. Kabel and Mohamed [2], improved the daily freshwater productivity for solar still with PCM by $67.18 \%$ than conventional solar still. Injection of hot air to the solar still by double passes solar air collector with Phase Change Material (PCM), have been experimentally investigated by Kabeela et al [3]. From the experimental results, it could be understood that freshwater productivity of the double passes solar air collector-coupled solar still with PCM is $108 \%$ higher than conventional still on average. Arjunan et al, $[4,5]$ made an attempt to enhance the productivity of conventional solar still by increasing temperature difference between water and glass, using different thick sponge liners at the inner wall surfaces. The authors concluded that (i) sponge liner stills works towards increasing the temperature difference between water and glass by reducing the temperature of glass (ii) solar still with $5 \mathrm{~mm}$ thick sponge liner gives more yield than the other sponge liner. Arunkumar et al, [6] with different augmentation system investigated the performance of compound parabolic concentrator assisted tubular solar still (CPC-TSS) and compound parabolic concentrator-concentric tubular solar still (CPC-CTSS).By means of heat extraction technique the productivity of CPC-CTSS with a single slope solar still and CPC-CTSS with a pyramid solar still as $6460 \mathrm{ml} /$ day and $7770 \mathrm{ml} /$ day, respectively was improved by them. Alaian et al [7], presented their findings on the performance of solar still amalgamated with pin-finned wick evaporation surface. The experimental measurements indicate that increase in distillate varies with ambient conditions. Enhancing the still productivity is also proved when pin-finned wick is applied in the still. Karimi et al [8] conducted an experimental and theoretical study on the productivity of a single-slope solar still with an internal reflector (IR). From the results it could be comprehended that simultaneous use of IR on front and side walls improves the still's efficiency by $18 \%$ and the increasing the cloud factor decreases the influence of IRs significantly. A study on effect of fin configuration parameters on single basin solar still performance was done by El-Sebaii et al [9]. From the study, it was found that productivity of the finned plate solar still (FBLS) increases while increasing the fin height and decreases when increasing the fin thickness and number. In this study, a new experimental approach is proposed to enhance the performances of conventional single slope solar still using vertical basin at inner wall surfaces. Main objectives of this study are, to increase the distilled output of solar still by utilizing heat energy available inside vertical surfaces by means of vertical basins and to find the optimum thickness of vertical basin.

\section{Experimental setup}

The experimental system involves six identical solar stills, one of the still is conventional and the others have vertical basin with different thicknesses $(3,6,9,12$ and $15 \mathrm{~mm})$. The basin liner is made of galvanized iron sheet of $0.009 \mathrm{~m}^{2}(30 \mathrm{~cm} \times$

6356 | P a g e 
$30 \mathrm{~cm}$ ) with maximum height of $160 \mathrm{~mm}$, and $1.4 \mathrm{~mm}$ thickness. Basin surfaces are painted with black paint to absorb the maximum amount of solar radiation incident on them. The height of vertical basin kept is $100 \mathrm{~mm}$. The still cover was made of window glass with thickness $4 \mathrm{~mm}$ and was tilted by $11^{\circ}$ with horizontal. Glass cover is framed with wood and sealed with silicon rubber. This has an important role in promoting efficient operation since it can accommodate the expansion and contraction between dissimilar materials. A collecting trough made by G.I. sheet is used in the still to collect distillate condensing on the inner surfaces of the glass covers and to pass the condensate to a collecting flask. Steel rule is fixed along with the inner wall for measuring water levels. The bottom and sides are insulated with glass wool. Geometrical construction of vertical basin arrangement in conventional solar still is shown in Figure 1, and pictorial views of the vertical basin arrangement and the experimental setup are shown in Figure 2 and Figure 3 respectively. The technical specifications and design parameters of the system are given in Table 1. The experiments are carried out in field conditions at the testing field of the Mechanical Engineering Department, Coimbatore Institute of Engineering and Technology, Coimbatore, Tamilnadu, India.

\section{Table 1 Technical specification and design parameters of the solar still}

\begin{tabular}{|l|l|}
\hline Specification & Dimension \\
\hline Basin area $\left(\mathrm{A}_{\mathrm{b}}\right)$ & $0.09 \mathrm{~m}^{2}$ \\
\hline Glass thickness & $4 \mathrm{~mm}$ \\
\hline Slope of glass & $11^{\circ}$ \\
\hline Vertical basin thickness & $3,6,9,12,15 \mathrm{~mm}$ \\
\hline Thermal conductivity of glass wool( $\left.\mathrm{k}_{\mathrm{th}}\right)$ & $20 \mathrm{~mm}$ \\
\hline
\end{tabular}

Figure1 Schematic of vertical basin arrangement in conventional still

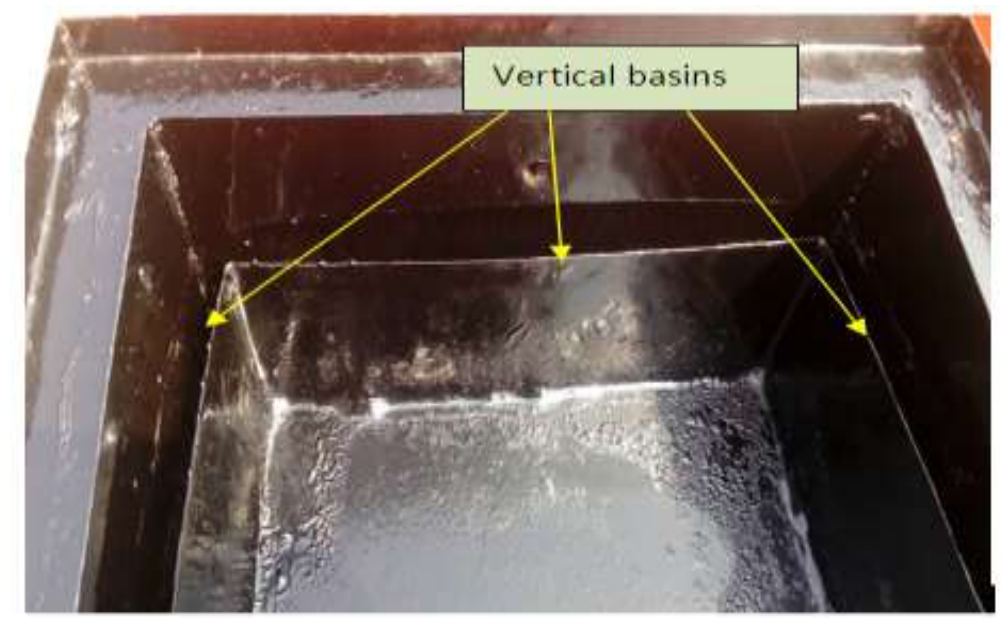

Figure 2 Pictorial view of vertical basin

$6357 \mid \mathrm{P}$ a g e 


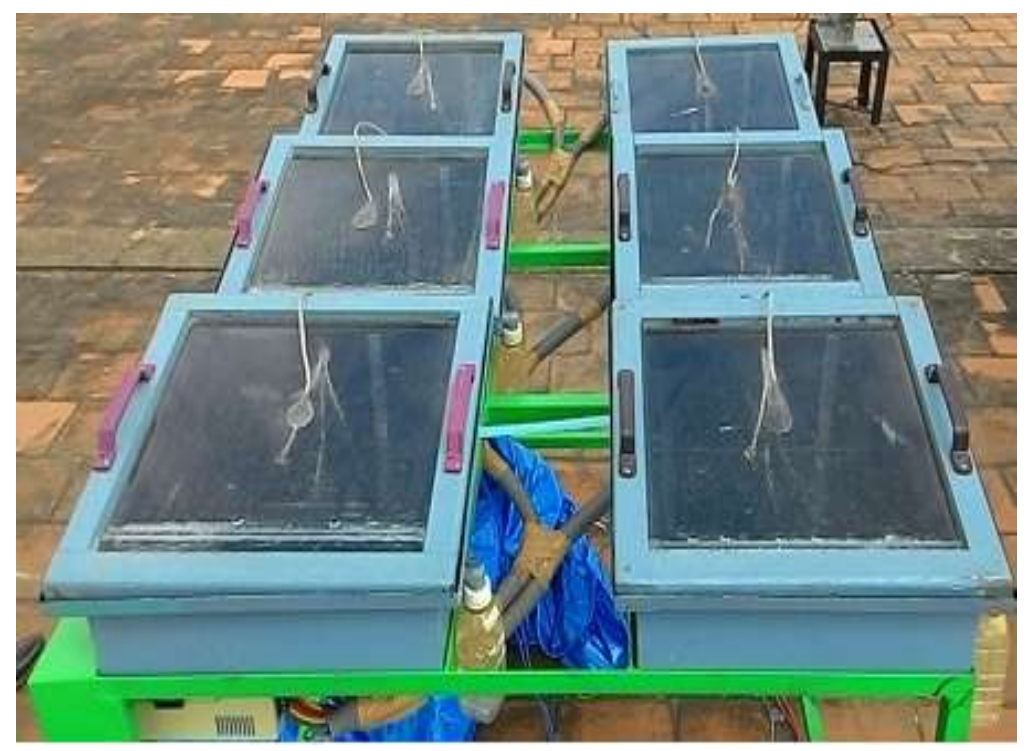

Figure 3 Pictorial view of experimental setup

The experiments on the still were carried out on 19.02.2016 for different vertical basin thicknesses. $20 \mathrm{~mm}$ water depth was maintained in the basin of the still [10] and 100mm height was maintained in the vertical basin. During experiments, the solar radiation intensity, ambient temperature, water temperature, basin liner temperature, inner wall temperatures and outer wall temperatures were recorded every sixty minutes. The hourly productivity of fresh water was collected through a graduated flask. The daily productivity is obtained as a summation of day and night productivity. The night productivity is the total collection from the end of test to start of test in the next day.

The measuring devices used in the system are:

1. A solar power meter is used to measure the solar radiation in $\left(\mathrm{kW} / \mathrm{m}^{2}\right)$.

2. Six thermocouples (type-k) coupled to digital thermometer with a range from 0 to $99.9^{\circ} \mathrm{C}$ with $\pm 1^{\circ} \mathrm{C}$ accuracy are used in each still to measure temperatures of the various components of the still.

3. A $15 \mathrm{~mm}$ steel rule is fixed inside wall used to measure water level.

\section{Result and Discussions}

The results and discussions for the behavior and performance of conventional and solar stills with vertical basins on the inner wall surfaces are presented in form of graphs. The experiments have been conducted from 9:00 hrs to 17:00 hrs under the climatic conditions of Coimbatore, Tamilnadu, India. It was covered with a wide range of parameters such as temperatures of basin liner, water, glass cover, inside back wall, outside back wall and hourly yield. The hourly solar intensity fall on the surface during the experimental day is shown in Figure 4 . The maximum solar intensity of $925 \mathrm{~W} / \mathrm{m}^{2}$ observed during $13.00 \mathrm{hrs}$ and the average solar intensity was $680 \mathrm{~W} / \mathrm{m}^{2}$.

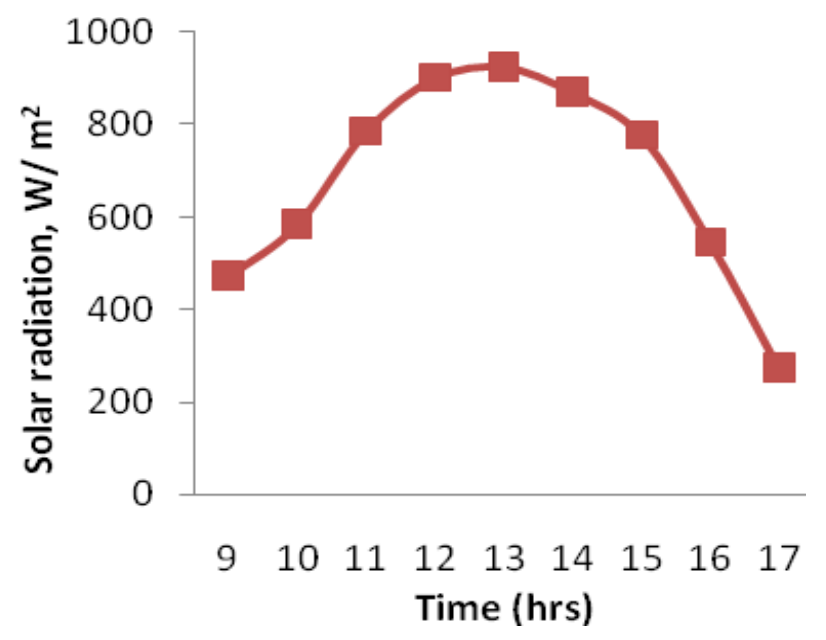

Fig.4 Solar radiation on 19.02.2016 


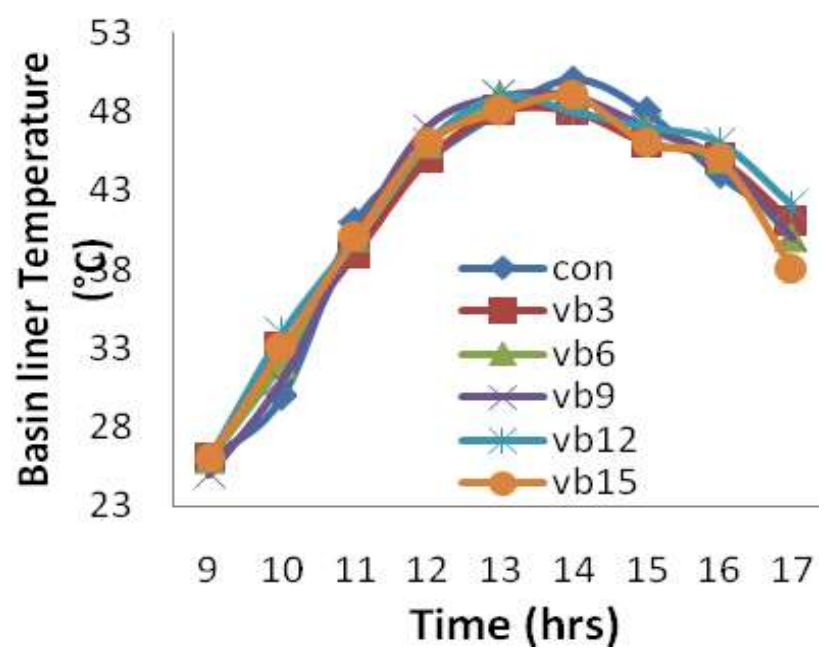

Figure 5 Basin liner temperatures

The basin liner and water temperature for the conventional and vertical basin solar stills are shown in Figure 5 and Figure 6. It clearly shows there is no much difference in the basin liner and water temperature throughout the day. But the vertical basins are influenced much on vapour temperature. It is vividly shown in Figure 7. The vapour temperature of conventional still is lower than vertical basin stills. It is due to the vapour coming out from the vertical basin mixed up with regular basin water vapour result gets higher temperature.

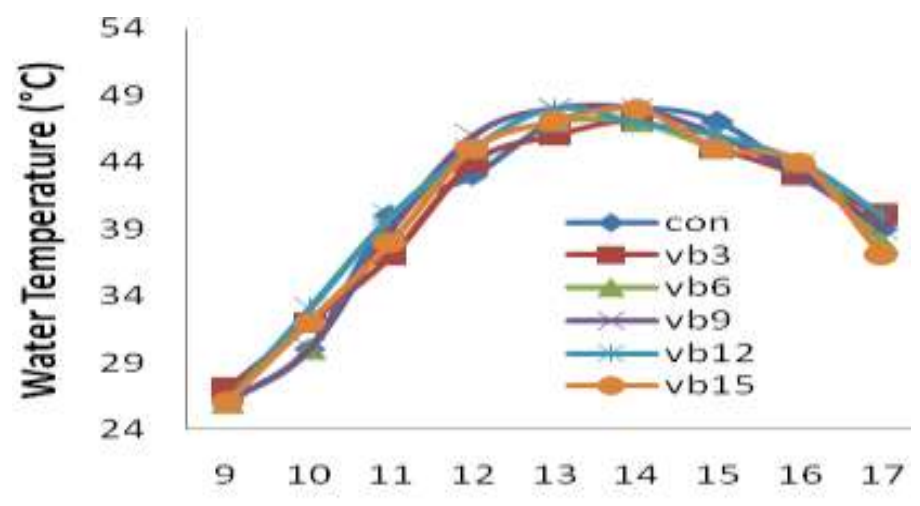

Time (hrs)

Figure 6 Water temperatures

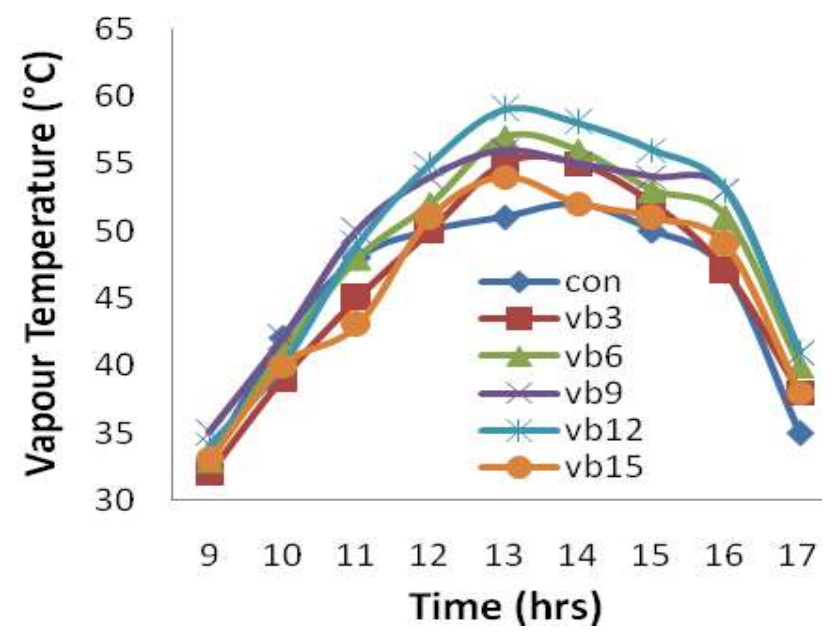

Figure 7 Vapour Temperature

6359 | P a g e 
The glass temperature of the still mainly depends on solar radiation absorptivity and heat extract from water vapour by means of condensation. It is understood from Figure 8, the glass temperature of $12 \mathrm{~mm}$ thick vertical basin still is higher than others. It is due to the higher condensation rate occurred at the glass surface. The previous statement is confirmed with reference to Figure 11.

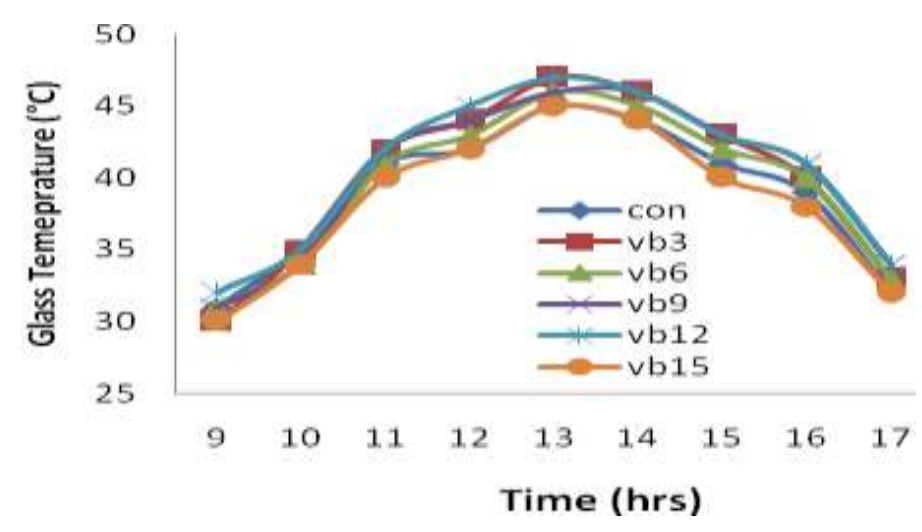

Figure 8 Glass Temperature

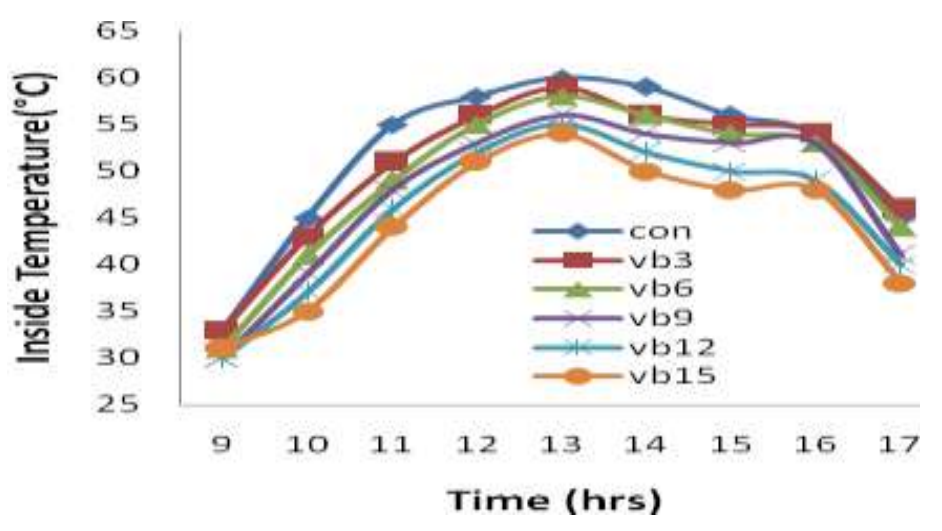

Figure 9 Inside back wall surface temperature

Figure 9 and Figure 10 depicts the inner and outer back wall temperature for conventional and vertical basin stills. It is seen that inside and outside back wall temperatures of conventional still is higher than vertical basin stills. It is due to the water available in the vertical surface extracts the heat and lowers the surface temperature. From Figure 10, it could be noticed that compared with conventional still, the heat flow from inner surfaces to the outer surfaces gets reduced in the vertical basin solar stills. This is the major advantage of vertical basin still over conventional still and energy saved from vertical surface is utilized for producing additional yield.

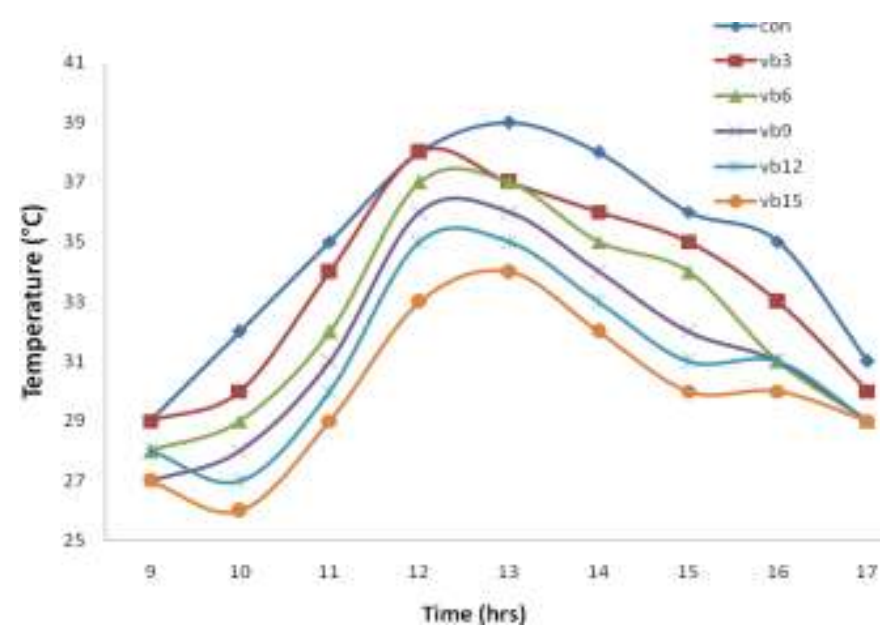

Figure 10 Outside back wall surface temperature

6360 | P a g e 


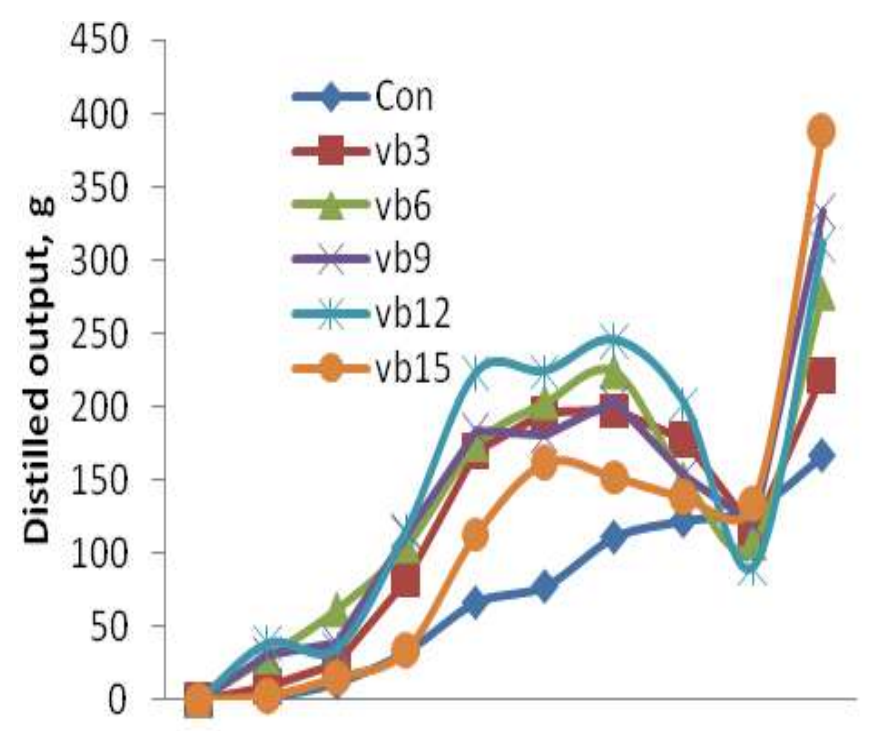

$9 \begin{array}{lllllllllll}9 & 10 & 11 & 12 & 13 & 14 & 15 & 16 & 17 & 17-9\end{array}$

Time (hrs)

Figure 11 Hourly distilled output

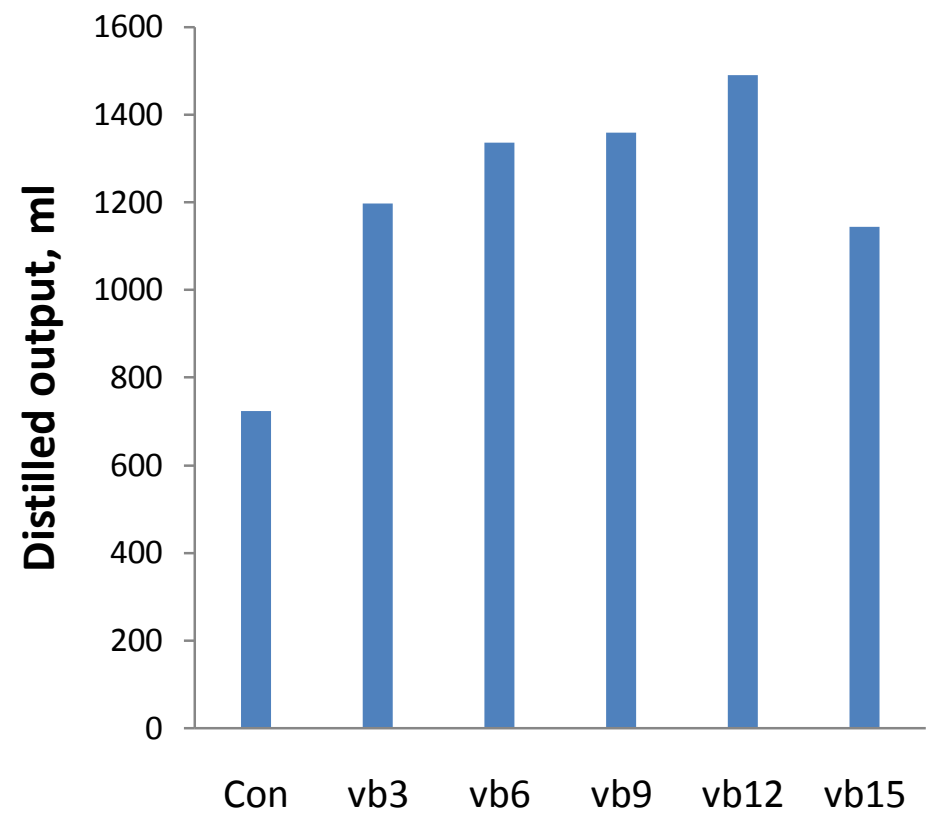

Figure 12 Distilled output

The productivity rate is increases until it reaches the maximum in the afternoon, then decreases in the late afternoon. Figure 11, clearly indicates that vertical basin stills produces more yield than conventional still throughout the day. It is also noticed that, after $11.00 \mathrm{hr}$ there is a sudden rise in the vertical basin still and it continues till $16.00 \mathrm{hrs}$. It is due to additional evaporation from vertical basins during this period. The maximum distilled output of $246 \mathrm{~g}$ was collected from 12 $\mathrm{mm}$ thick vertical basin still at $15.00 \mathrm{hrs}$. The Figure 11 also shows that night time productivity is higher in vertical basin stills; it is due to high thermal capacity in the vertical basin water. The maximum night time productivity of $390 \mathrm{~g}$ was collected from $15 \mathrm{~mm}$ thick vertical basin solar still. Figure 12 shows the daily yield of conventional and vertical basin solar stills. It could be understood that $12 \mathrm{~mm}$ vertical basin yield is higher than the other stills. This may be due to the quantity of water; energy availability and area of vertical surfaces are reaches optimum value to produce maximum yield. The yield of $12 \mathrm{~mm}$ thick vertical basin still is $1490 \mathrm{~g} /$ day, which is $106 \%$ higher than conventional solar still. 


\section{Conclusions}

In this experimental study investigation is made on the effect of vertical basins on the inner wall surface in solar still. Total numbers of six solar stills are used for this study. Among them one is conventional and others are modified with vertical basins. The different thicknesses of vertical basins is tested, and is compared the data of conventional solar still. The results of the study could be summarised as:

- Inner surfaces of the solar stills store considerable amount of heat energy.

- Vertical basins at the inner wall surfaces increase the yield by $106 \%$ than the conventional still and reduce the conductive heat loss through the inner wall surface to the outer wall surfaces.

- Thicknesses of vertical basin influence the productivity of the solar still, and optimum thickness of vertical basin is $12 \mathrm{~mm}$.

The present study could be extended for single slope single basin solar still that includes:

- Developing a mathematical model to validate experimental results by writing energy balance of the still components like basin liner, glass, and water.

- Studying water depth in vertical basin on the solar still output.

- Current study could be extended for double slope passive solar stills.

\section{References}

1. Omara, Z.M., Kabeel, A.E, Abdullah, A.S., and Essa, F.A.: Experimental investigation of corrugated absorber solar still with wick and reflectors. Desalination. 381, 111-116 (2016).

2. Kabeel, A.E.: Mohamed Abdelgaied, Improving the performance of solar still by using PCM as a thermal storage medium under Egyptian conditions. Desalination. 383, 22-28 (2016).

3. Kabeel, A.E.: Mohamed Abdelgaied, Mahgoub M, The performance of a modified solar still using hot air injection and PCM. Desalination.379, 102-107 (2016).

4. Arjunan, T.V., Aybar, H S, Nedunchezhian, N.: The effect of sponge liner on the performance of simple solar still. International Journal of Renewable Energy Technology. 2, 169-192 (2011).

5. Arjunan, T.V., Aybar, H S, Nedunchezhian, N.: Effect of sponge liner on the internal heat transfer coefficients in a simple solar still. Desalination and Water Treatment.29, 271-284 (2011).

6. Arunkumar, T, Velraj, R, Denkenberger, D.C., Ravishankar, S, Vinothkumar, K, Amimul Ashan.: Productivity enhancements of compound parabolic concentrator tubular solar stills. Renewable Energy. 88, 391 - 400 (2016).

7. Alaian, W.M., Elnegiry, E A, Ahemed, M H.: Experimental investigation on the performance of solar still augmented with pin-finned wick. Desalination. 379,10-15 (2016).

8. Karimi, E M R, Amimul, A, Mehrzad, F, Khosrow, J, Seyedsh Saba, A F, Mansoor, F.: Theoretical and experimental investigation on internal reflectors in a single-slope solar still. Applied Energy. 165, 537-547 (2016).

9. El- Sebaii, A A, Ramadan, M. R. I, Aboul Enein, S, El Naggar, M.: Effect of fin configuration parameters on single basin solar still performance. Desalination. 365,15-24 (2015).

10. Arjunan, T.V., Aybar, H S, Nedunchezhian, N.: Effect of water capacity on the performance of a simple solar still. International Journal of Applied Engineering Research. 4, 2223 - 2234 (2009). 